\title{
The Developing Model of Academic Supervision Based on quality at MTsN Brebes Central Java Indonesia
}

\author{
Kasturi $^{1}$, Masrukhi $^{2}$, Rusdarti $^{2}$, Joko Sutarto $^{2}$ \\ \{Kasturi1302@gmail.com, masrukhi@unnes.ac.id, rusdarti@unnes.ac.id,jokotarto@unnes.ac.id\} \\ ${ }^{1}$ Post Graduate Student at Universitas Negeri Semarang, Indonesia \\ ${ }^{2}$ Post Graduate Universitas Negeri Semarang, Indonesia
}

\begin{abstract}
This research is the development of academic supervision based on quality at MTsN Brebes Central Java. Research design used research and development (R \& D). the results of this study indicate that the academic supervision applied at Brebes MTsN has not been implemented well. Development is carried out by improving quality, which is based on educational quality standards, including graduation standards, assessment standards, content standards and process standards. academic supervision model based on quality is the development of the previous academic supervision model. With the existence of a quality-based academic supervision development model, it is expected that maximum academic supervision can be achieved.
\end{abstract}

Keywords: academic supervision, development model, quality

\section{Introduction}

Law Number 20 of 2003 concerning the National Education System states that the National Education System is the whole component of education that is interrelated in an integrated manner to achieve national education goals, namely to develop capabilities and improve the quality of life and human dignity of Indonesia. The fulfillment and quality assurance of education is the responsibility of each component in the education unit. Educational quality assurance in educational units cannot run well without a quality culture in all components of the education unit. Therefore, the implementation of the education quality assurance system in educational units is carried out with the approach of involving all components of the education unit so that all components of the education unit together have a quality culture.

The basic and secondary education quality assurance system is developed so that quality assurance can run well in all levels of management of primary and secondary education. The primary and secondary education quality assurance system consists of two components, namely the Internal Quality Assurance System (SPMI) and the External Quality Assurance System (SPME). SPME is a quality assurance system implemented by the government, regional government, accreditation institutions and standardization of education institutions. SPMI is a quality assurance system that runs in an educational unit and is run by all components in an educational unit.

SPMI, referred to as the education quality assurance system in educational units, covers all aspects of the implementation of education by utilizing various resources to achieve SNP. The education unit applies the entire cycle in the quality assurance system independently and continuously to build a quality culture in the education unit. Quality culture will encourage 
education units to improve the quality of education continuously so that the quality of education will increase consistently over time gradually until the standards are met or even exceed these standards. The quality assurance system is evaluated and developed continuously by the education unit to be determined by the education unit and set out in the guidelines for managing the education unit and disseminated to the education unit stakeholders.

Academic supervision by the principal and the supervision team as a series of process activities to provide assistance to the teacher in the management of learning is interpreted as a sequence of stages of relief actions given by the principal and / or supervision team to teachers who have difficulty in carrying out their learning performance. The intended sequence of activities is planning, implementing, evaluating, reporting, and following up on the principal's academic supervision [1],[2],[3]

The development of quality-based academic supervision models is expected to contribute to the quality of education in Brebes Regency, especially in MTsN. Quality is expected to refer to Law Number 20 of 2003 concerning the Education System. The purpose of this study was to analyze the current factual academic supervision model, analyze the hypothetical model of quality-based academic supervision, and find the final model of academic supervision based on quality, as well as its benefits and contributions to the quality of education.

\section{Method}

The research was conducted with research and development design or Research and Development (R \& D), [4] This design is considered to be very suitable with the purpose of the research, namely to produce certain products and test the effectiveness of these products. The products developed and produced in this study are quality-based academic supervision models to improve the competence, professionalism, and performance of MTs teachers in Brebes Regency. R \& D design can be carried out through several steps as developed by experts. Educational research and development is a process of developing and validating educational products, 10 steps of research and development, namely: (1) research and information gathering; (2) planning; (3) preliminary product development; (4) preliminary trials; (5) revisions to the main products; (6) main trials; (7) revision of operational products; (8) operational trials; (9) final product revisions; and (10) dissemination and distribution. 10 steps that researchers must take in explaining the $\mathrm{R} \& \mathrm{D}$ design. In this study, the ten steps are summarized into three research stages, namely (1) the preliminary study phase and the design of the model; (2) model development stage, and (3) model evaluation stage. Collecting data used observation, questionnaire and interviews. Analyze of data used quantitative and qualitative analyze.

\section{Result and discussion}

\subsection{Factual model of academic supervision at MTsN Brebes}

Management planning supervision includes; target supervision, supervising work program, and planning time supervision; the implementation of supervision includes: the stage of the initial meeting of the supervisor with supervie, the observation stage of the supervisor with supervie, and the follow-up stage between the supervisor and supervie. the supervision evaluation stage includes: evaluating the principal's academic supervision (evaluating the initial 
meeting, evaluating the implementation, and evaluating the final stage of the meeting), followup supervision including follow-up on giving the school principal reflection on teacher weaknesses, offering solutions, teacher commitment in following up, support and reporting of academic supervision. Variable supervisors in supervision include the competency of the principal as a supervisor, the task of the principal as a supervisor, and the role of the principal in academic supervision. Teacher competency includes teacher competencies in planning the implementation of learning, namely mastery of the teacher in the administration of learning tools, learning components, and mastery of learning steps. Variable material used, methods used and infrastructure used. Based on the data analysis conducted, it shows that the academic supervision carried out by the principal in Brebes Regency MTs is still not maximal, and lacks good quality, therefore a quality supervision model is needed, so that the implementation of academic supervision can run effectively.

Based on the results of data analysis in the preliminary study, it can be concluded that academic supervision in the MTs of Brebes Regency has not run ideally. Each stage of academic supervision has not been carried out in accordance with predetermined quality and quality standards. Guiding in opinion [5],[6],[7],[8] states that the supervision that has been carried out by supervisors and principals for teacher professional development has not been effective. The supervision program plan was prepared but it was not implemented properly. At the planning stage in the preparation of the supervising work program by the school principal is less comprehensive so that the substance of the explanation about planning, implementation and evaluation is unclear, giving rise to misunderstanding of supervised teachers. Planning for the supervisor's academic supervision program does not identify the most crucial problems faced by the teacher. The weakness of work programs that are not in accordance with conditions in schools shows that principals are less able to develop measurable, realistic work programs [8],[9],[10],[11],[12],[13],[14].

The stage of implementing academic supervision at MTs in Brebes Regency was not optimally carried out by the principal. The weakness of the school principal's accuracy in overseeing the completeness, suitability of the material, and the method of the teacher in the implementation of learning raises a mismatch of conditions with the learning process in the classroom, so that the learning process does not run democratic, and the output is only at the level of results and not processes. The lack of knowledge of the principal towards the evaluation method or technique resulted in the implementation of supervision running rhizomes. The evaluation stage becomes an important tool in the activities of academic supervision. Evaluation determines whether academic supervision is successful or not. The weakness in academic supervision at MTs in Brebes Regency is the lack of reflection made by the principal on teacher weaknesses so that the problems found in academic supervision have not been fully resolved.

Other weaknesses found in the preliminary study indicate that the reporting of academic supervision carried out by the principal has not been done comprehensively and comprehensively. The school principal's academic supervision report is ideally reported to the supervisor, committee and teacher. So from that final conclusion of this model is that the supervision can be done to the maximum that needs to be emphasized is that the principal must have the ability to comprehend the substance of academic supervision comprehensively, and the reporting is aimed at making academic supervision activities run optimally.

\subsection{Hypothetical model}

The quality of academic supervision in schools is inseparable from government regulation No. 19 of 2005 concerning national education standards. This government regulation 
provides direction on the need to compile and implement 4 national education standards which include: content standards, process standards, graduation competency standards, and educational assessment standards, and comprehensive reporting standards. Graduation standards include; the principal has knowledge about the assessment of attitudes, knowledge and skills. Standard content includes; the ability of the principal to understand the design of competencies and scope of material in the Education Unit Level Curriculum (KTSP) / syllabus in accordance with the national curriculum, Understanding subject design and learning burdens give sufficient time to develop various attitudes, knowledge, and skills, have understanding devices development of KTSP, socializing the device to stakeholders, involving stakeholders in the preparation of KTSP. Process standards include; Having knowledge of various learning approaches, Having skills in planning learning, Having skills in implementing learning, Having learning assessment skills. Assessment standards include; The assessment process is valid, objective, open, authentic, systematic, accountable, and educative. The education unit applies authentic assessments, forms of assessment documents in accordance with applicable rules.

\subsection{Graduation Standards}

Distribution of respondents from MTs head variables must have the ability to describe graduation criteria in terms of attitude, knowledge and skills, as a whole has a mean of 3.7. The mean is divided into attitude assessment criteria of 3.6; knowledge assessment criteria of 3.6; and skills assessment of 3.7. Based on the results of the distribution of respondents from questionnaire questions, it was concluded that the head of MTs in Brebes was very important in order to understand the graduation criteria, both graduation attitudes, knowledge and skills.

Conclusions about the head of MTs in Brebes must have knowledge of graduation criteria, confirmed by interviews with the North Supervisor, as follows:

"It is very important for school leaders in Brebes District MTs to have the ability to assess both attitudes, knowledge and skills. Graduation of attitude is seen from behavior that reflects the attitude of a believer, has a noble character, is knowledgeable, confident, and is responsible for interacting effectively with the social and natural environment in accordance with the scope of education. Graduation of knowledge Having factual, conceptual and / or procedural and metacognitive knowledge about science, technology, art, and culture in humanity, nationality, state and civilization insights related to phenomena and events according to the scope of education, as well as graduating skills Having thinking and acting skills productive and creative in the abstract and concrete realm as expected at every level of education ".

\subsection{Content Standard}

Distribution of respondents' questions about content standards, as a whole has a mean of 3.6. The results of the distribution are described as follows; the ability of the principal to understand the design of competencies and the scope of material in the Education Unit Level Curriculum (KTSP) / syllabus in accordance with the national curriculum has a mean of 3.5; Average Understanding The design of subjects and the burden of learning give sufficient time to develop various attitudes, knowledge, and skills at 3.8; average Has an understanding of the KTSP development device of 3.6; Disseminate the device to stakeholders at 3.6; and Involving stakeholders in the preparation of KTSP of 3.4. 
Based on the results of the distribution of respondents' answers, it was concluded that the needs of the head of MTs in Brebes in understanding standard content indicators were very important. Head of MTs is required to have qualified knowledge in understanding the education curriculum, list of subjects and time allocation according to the standard class time per week according to the standard, the burden of tuition per semester is according to the standard.

The reinforcement interview statement that MTs principals in Brebes must have knowledge of the school curriculum, explained by the MTs supervisor at the same time, as follows:

"MTs principals are very important to understand the school curriculum that has been set. The school curriculum is used to guide in determining the educational process at school. The school curriculum includes, the number of hours of subjects in one week, the learning burden per semester in accordance with the standard, and can determine the local content curriculum that is tailored to the conditions of each school ".

\subsection{Process Standard}

The distribution of analysis of the needs of MTs principals in Brebes Regency on the standard process variables, as a whole has a mean of 3.7, which can be interpreted that the ability of school principals to understand the process of education in schools is very important. The ability of the principal includes; Have knowledge of various learning approaches; Having skills in planning learning; Having skills in implementing learning; Have assessment skills and learning assessment techniques.

The ability of principals to understand process standards is becoming mainstream in education in schools. The standard process determines the learning process, and the process of achieving learning outcomes, especially from indicators of knowledge of various learning approaches. The learning approach determines the scheme of making plans for implementing learning, learning objectives and learning outcomes. The obstacle that often occurs is the lack of knowledge of the principal towards approaches, methods and learning strategies.

The reinforcement statement is described from the interview of the MTS Supervisor in the South, as follows:

"The weakness of MTs principals in Brebes Regency is that they do not have sufficient level of knowledge from various learning approaches. The concept of the approach understood by most principals is still very minimal, especially with regard to the compatibility between the approach and the method used. These difficulties lead to incompatibility between concepts and actions taken. Ideally, the principal must be able to analyze learning approaches, and integrate them with the methods or techniques used in learning.

\subsection{Assessment Standards}

The answer distribution of the needs analysis from the standard assessment of the principal in academic supervision activities shows an average of 3.7. The need for assessment conducted by the principal to be valid, objective, open, authentic, systematic, accountable, and educative reaches a mean of 4 (Appendix). This shows that so far school principals have not fully demonstrated an assessment that is in accordance with the ideal standardization of assessment.

"The assessment of principals in academic supervision activities often forgets a comprehensive assessment mechanism. The assessment needs of each learning process are very important for teachers, and as principals knowledge about the ideal assessment mechanism and how its implementation becomes a need that should not be 
abandoned. Authentic assessment has not been carried out by the principal so far. " (Interview with southern MTs supervisor).

\subsection{Responsibility for Academic Supervision Report}

Distribution of the results of respondents' answers about the accountability reports of academic supervision by the principal from the indicator that the principal must provide an academic supervision report to the supervisor having a mean of 4.0, supervision reports to the teacher 4.0, and supervision reports to the committee of 3.2. Based on the results of the respondent's answers, it was indicated that the principal as a supervisor must report, both to the supervisor and the teacher, which had not been fully carried out.

Strengthening the arguments of respondents' answers was stated both by teachers and supervisors in the southern part of Brebes district, with the following statements:

"The principal's accountability report on the assignment as a supervisor, the ideal is very necessary, because it contains how far the ability and capability of a supervisor to carry out the task properly. Reflection, strengthening and guidance functions must also be carried out by supervisors when they find school principals who have not carried out the accountability report to the maximum ".

\subsection{The final model academic supervision based on quality}

The final model is a revision of the hypothetical model of quality-based academic supervision, based on the results of limited trials, extensive trials and input from experts and practitioners through the FGD. In the final results carried out by experts / experts and practice on the hypothetical model obtained very good responses, and some suggestions for improving the model.

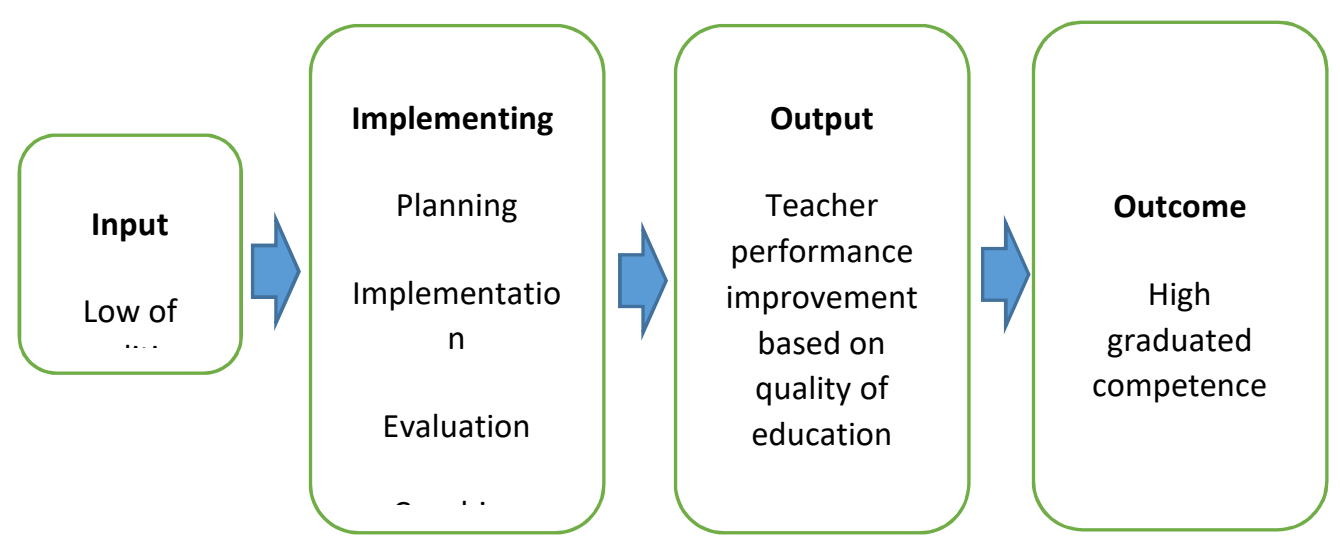

Figure 1. Final Model Academic Supervision Based on Quality

\section{Conclusion}

The factual model of academic supervision conducted at MTsN Brebes, from planning, implementation and evaluation, as well as follow-up has not been carried out maximally. The 
weakness of the academic supervision activities is indicated by the still low quality of education at the Brebes MTsN. The hypothetical model is a design study of the conceptual model offered by based on the needs analysis, about quality standardization in Law No. 3 of 2004, about graduation standards, content standards, process standards and assessment standards. The final model found about the effectiveness of the models found, with the aim of creating quality quality academic supervision, so that it could be applied to Brebes MTsN as a whole. 


\section{References}

[1] dkk Manggar, Johannes, Supervisi Akademik Kepala Sekolah. Jakarta: Kementerian Pendidikan Kebudayaan Lembaga Pengembanga dan Pemberdayaan Kepala Sekolah (LPPKS) Indonesia., 2011.

[2] S. Gultom, Bahan Ajar Diklat Supervisi Kepala Sekolah. Jakarta: Kementerian Pendidikan dan Kebudayaan., 2014.

[3] G. S. Utami, Modul Supervisi KepalaSekolah Pembelajar. Jakarta : Direktorat Jenderal Guru dan Tenaga Kependidikan, Kementerian Pendidikan dan Kebudayaan Republik Indonesia., 2016.

[4] M. . Borg, W.R.., and Gall, Educational Research. 8th Edition. Michigan. Pearson Education, 2007.

[5] A. Y. Muhajirin,Titi Prihatin, "Pengaruh Supervisi Akademik dan Partisipasi Guru pada MGMP Melalui Motivasi Kerja Terhadap Profesionalisme Guru SMA/MA,” Educ. Manag., vol. 6 , no. 2, pp. 170-177, 2017.

[6] I. M. S. Ridwan Samsu1, Wahyu Hardyanto, "Efektifitas Model Supervisi Akademik Online pada Guru Sekolah Menengah Kejuruan,” Educ. Manag., vol. 6, no. 2, pp. 95-99, 2017.

[7] S. S. Eliani Dwi Pahlevie, S. Matono, "Model Supervisi Akademik Berbasis Evaluasi Diri Guru Dan Penilaian Rekan Sejawat,” Educ. Manag., vol. 3, no. 4, 2014.

[8] M. S. Muhammad Juaini, Rusdarti, "Supervisi Akademik Berbasis Pelayanan Prima Pada Guru SMA Di Kabupaten Lombok Timur,” Educ. Manag., 2016.

[9] S. D. Rusdarti, "Akuntabilitas Penjaminan Mutu Terhadap Akreditasi Program Studi di Pascasarjana Universitas Negeri Semarang," Educ. Manag., vol. 2, no. 196-207, 6AD.

[10] S. Sagala, Supervisi Pembelajaran. Bandung: CV. Alfabeta, 2000.

[11] N. Sudjana, Supervisi Pendidikan Konsep dan Aplikasinya bagi Pengawas Sekolah. Jakarta: Binamitra-Publishing, 2004.

[12] Sugiyono, "Pengaruh Supervisi Pembelajaran Dan Komunikasi Terhadap Kinerja Guru SD Negeri Di Kecamatan Ngampel Kabupaten Kendal Tahun 2009,” Educ. Manag., vol. 1, no. 1, 2012.

[13] N. N. Putu Prapta, Nyoman Dantes, "Hubungan Kualitas Pengelolaan, Supervisi Akademik Kepala Sekolah dan Iklim Kerja Terhadap Kinerja Guru SMP Negeri di Kabupaten Jembrana," e-Journal Progr. Pascasarj. Univ. Pendidik. Ganesha Jur. Pendidik. Dasar, vol. 3, 2013.

[14] Priansa dkk, Manajemen Supervisi dan Kepemimpinan Kepala Sekolah. 2014. 